日本に打ける家庭電力消費量の

地域的パターン

中川正

\section{I.はじめに}

わが国においては，第二次世界大戦後の高度経済 成長に伴う所得の増加を背景に, 個人の消費が急速 に桩大し，また多様化してきた。わが国では，その 消費の拉大が電気製品購入への支出増加という形に 現われたことが，一つの大きな特徴であり，これは， 多くの人々が，しばしば家庭の近代化を電化と同義 語とみなすほどであった。家庭の近代化を進めよう とする人々の意識は, テレビ, ステレオ, クーラー 等を, その時々の家庭の生活水準の象徵とし，電気 製品の購入を, 人々の所得向上の目的の一つにさせ てきた。したがって,この家庭内の近代化や生活水 準の程度を示す一つの指標として，家庭電気製品の 保有状況や使用状況を総合的に反映する家庭電力消 費量を考えることは適当であ万う。そして，その地 域的分布や, 年次的变化の地域差が, 地理学研究の 対象となろう。

家庭電力消費量の分布には，地域の人々の伝統的 な生活意識と, 個人所得, 就業構造, 人口構成, 家 の広さ, 気温等の, 経済・社会・自然条件が反映し ているものと考えられる。

ところで経済・社会・自然的諸条件による家庭電 力消費量の地域差の説明は, 従来主に経済学の分野 から行われてきた。佐久間・荒井 ${ }^{1)}$ は，都道府県別 1 世帯あたりの従量電灯消費量の地域差を, 所得, 貯蓄, 職業構成, 前年度消費量等の要因によって説 明した。また電力中央研究所 ${ }^{2)}$ は, 都道府県別 1 世 帯あたりの電灯消費量を家計消費支出, 世帯あたり の畺数, 家庭電化指標 ${ }^{3}$, 冷房・暖房日等の諸要因 による回帰分析で説明した。しかしこれらは, 需要 予測を目的とするものであるため, 地域性を適切に 表現し, 直接の要因となる条件のみが考察されてき たとは言い難い。また 1 ないし 2 時点のみの家庭電 力消費量が対象とされているため, その分布形態は 一般的か否かは明らかでない。
これらの経済学的研究は, 経済学の性質上,地域住 民の伝統的な生活意識の地域差を直接の考察対象と していない。しかし, 地理学の分野で, 電力消費量 の分布から地域性を解釈しょうとした研究は少な く，研究課題として残されている。

本稿はこのような認識のもとに, 日本の高度経済 成長期を含む $1960 ， 1965 ， 1970 ， 1975$ 年の都 道府県別 1 世帯あたりの家庭電力消費量の分布に現 われた, 各地域の伝統的生活意識と, 経済・社会・ 自然条件との複合である地域性を明らかにしようと するものである。そのため, 家庭電力消費量分布を 従属変数とみなし，これに直接影響を与えると考え

第 1 表 電力契約種別

\begin{tabular}{|c|c|c|}
\hline 需要区分 & 契 約 種 & 別 \\
\hline \multirow{3}{*}{ 電 } & 額 & 灯 \\
\hline & \multirow{3}{*}{ 従 量 電 灯 } & 甲 \\
\hline & & 乙 \\
\hline \multirow[t]{2}{*}{ 灯 } & & 丙 \\
\hline & \multirow{3}{*}{ 臨＼cjkstart時＼cjkstart電＼cjkstart灯 } & 甲 \\
\hline 需 & & 乙 \\
\hline \multirow{3}{*}{ 要 } & & 丙 \\
\hline & \multirow{2}{*}{ 公衆街 路 灯 } & 甲 \\
\hline & & 乙 \\
\hline \multirow{4}{*}{ 電 } & 業 務 ${ }^{\circ}$ 用 電 & 力 \\
\hline & 低 圧 電 & 力 \\
\hline & \multirow{2}{*}{ 高 圧 電 力 } & 甲 \\
\hline & & 乙 \\
\hline \multirow{2}{*}{ 力 } & \multicolumn{2}{|c|}{ 特 別 高 圧 電 力 } \\
\hline & 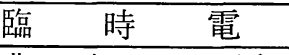 & 力 \\
\hline \multirow{2}{*}{ 需 } & 農 事 用 電 & 力 \\
\hline & \multirow{3}{*}{ 予 備 電 力 } & 甲 \\
\hline \multirow{4}{*}{ 要 } & & 乙 \\
\hline & & 丙 \\
\hline & \multirow{2}{*}{ 樑 夜 電 力 } & 甲 \\
\hline & & 乙 \\
\hline
\end{tabular}

資料「東京電力株式会社電気供給規定」昭和 51 年 
られる $2 \sim 3$ 種の条件を独立変数として回帰分析を 行い考察する。

家庭電力は, 家庭内で消費される生活用電力とし て定義される。しかし，家庭電力消費量のデータの みを, 他の電力消費量から悠密に区別して抽出する ことは実際には不可能である。電力会社は, 需要家 との電力契約を契約電流や電気供給方式等によって 数種の種別に分けている(第 1 表)。本稿では, デ 一夕入手の関係上, 家庭電力消費量を, 定額 ・従量 。臨時電灯および公衆街路灯からなる電灯消費量に 置きかえて考察する。電灯消費量のうち, 家庭電力 消費量に相当するものは, 従量電灯の甲および乙で あると考えられる がっここれ，1977 年において 電灯消費量の $82.3 \%$ を占め)，電灯消費量の地域差 や動向を支配する要素となっている。

本研究の目的を遂行する前提として, まず電灯消 費量の 1960 年以降の推移を見ることによって, 電 灯消費量の経年的特徵を把握する。つぎに，家庭電 力消費量を直接に規定すると考えられる条件の性質 を検討し, 本研究の分析に用いる要因を抽出する。 さらに 1960，1965，1970，1975 年における都 道府県別 1 世帯あたりの電灯消費量の分布と, 電灯 消費量増加率の分布を見ることによって, 電灯消費 量分布の空間的性質を把握する。これらの前提のう えで, 日本における電灯消費パターンを地図化して, 電灯消費量から見た各地域の地域性を考察する。な お, 沖繩県は, 統一的なデータが得られなかったた め, 研究対象から除外した。

\section{II。電灯消費量の推移とその規定要因}

\section{1. 電灯消費量の推移}

経済変動が電灯消費量におよぼす影響と, 電力消 費量におよぼす影響とを比較することによって，電 灯消費量の経年変化の特徴を 把えてみよう(第1図)。 日本の高度経済成長は，1960 年代に 本格的に進 み。実質国民総生産は 1960 年から 1970年までの 10 年間に 3.9 倍になった。1950 52 年の朝鮮戦争を 契機として，1955年から重化学工業中心の工業化 が進められ，1960 年代には日本の産業の構造変化 が進んだ。重化学工業の発展は, 農業労働力を都市 に吸収し，1960年には $32.6 \%$ であった第 1 次産業 就業者率は，1970 年には $19.4 \% に$ に減少した。 都市への人口集中によって，大都市周辺地域の都市

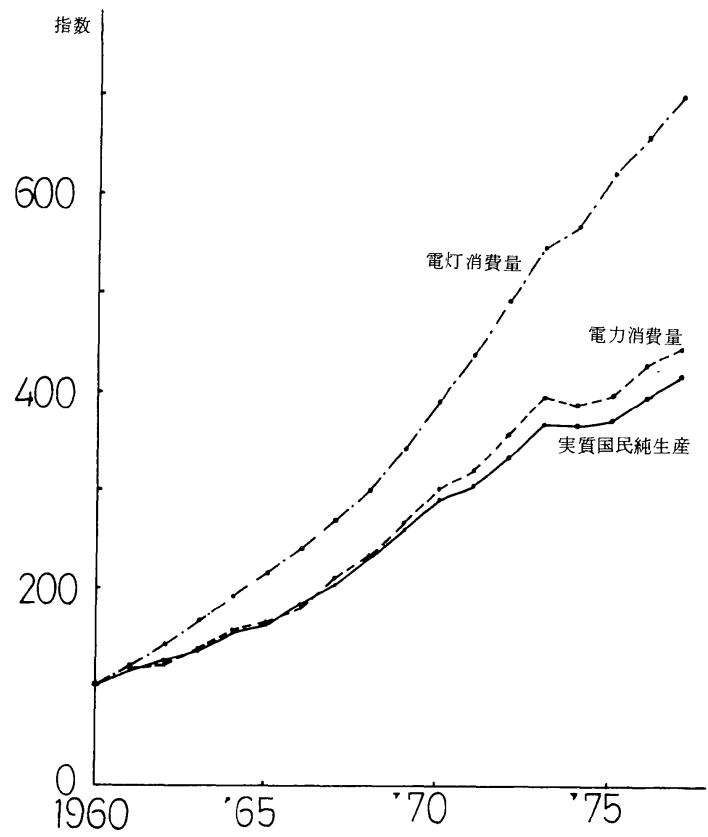

\section{第 1 図 電灯・電力消費量指数および実質国民総生} 産指数の推移

資料「電気事業便覧」電気事業連合会編，1978 「経済要覧」経済企画庁編, 1979. (1960年の数值を 100 とする指数で示す)

化が進むと同時に，農村内部の生活様式も都市的な ものに変化してきた。1960-1970年には年平均 $11.2 \%$ であった国民総生産の成長率は，1970年代 に入って鈍化し，1973 年のオイルショック時には, 国民総生産が減少するまでに至った。1975 年以降, 成長率は回復してきたが，わが国は高度経済成長か ら安定成長へと方向転換してきたといえよう。しか し，農業労働力の減少は依然として進行しており, 1975 年には, 第 1 次産業就業者率は $13.9 \%$ にな た。

電力消費量は，国民総生産とよく対応した変化を みせてきた。1960年代に急激に発展 した重化学工 業には，大量に電力を消費する部門が多いため，そ れに対応して発電方式も, 水力中心から, 重化学工 業地域内に立地する火力中心に移ってきた。電力消 費量は, 経済変動の影響を受けやすく。1974 年の 電力消費減少率は $2.1 \%$ ， 国民総生産の 減少率の $0.6 \% よ り$ \%きい。この原因としては, オイルシ ヨックに伴う総需要抑制策やエネルギー消費規制運 動, 夏季の低温による冷房用電力需要の伸び悩み, 電気料金の值上げ等が考察されている

これに対して電灯消費量は，1960-1977年で7.0 


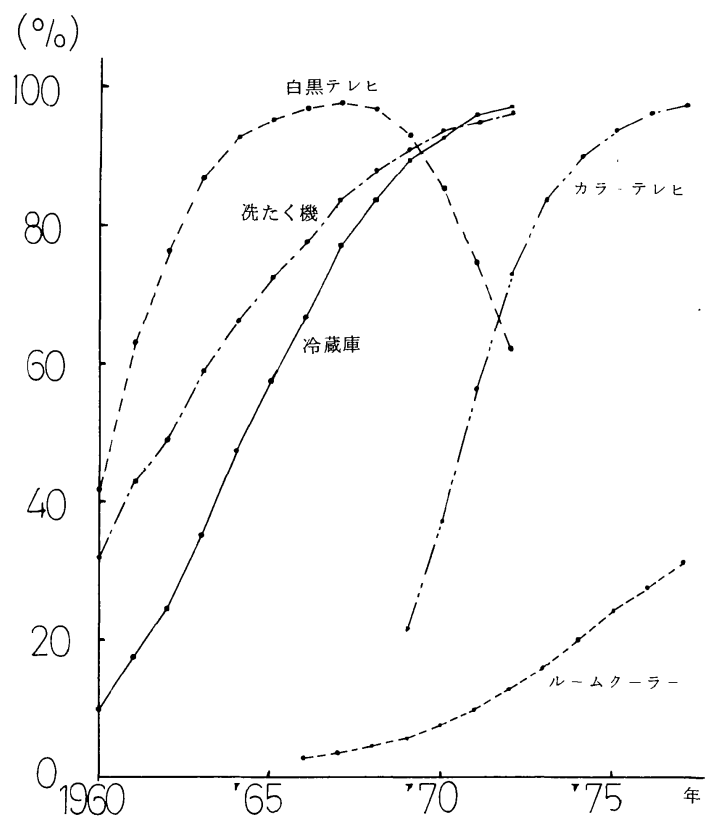

第2図 主な家庭電気機器の普及率の推移

資料「 B. B. R.」中央調査社

倍と飛躍的に増加しており, 電力消費量の 4.4 倍, 国民総生産の 4.2 倍よりも大きい。この増加は，家庭 内の電化が急速に進展したことを示している。1950 年代後半から普及し始めた白黒テレビは, 1963 年に は普及率が $86.5 \%$ に達し,それと重なって 1960 年 代後半には洗たく機や冷蔵庫の普及率が飽和状態に 達した (第 2 図)。1960 年代後半から1970年 代 初期にかけてカラーテレビが急速に普及し，1971 年 のドルショックにほとんど影響をうけずに電灯消費 量は増加した。1973ー1974年には電灯消費増加 率は減少したが，電力消費量のように絶対量が減少 するまでには至っていない。家庭電力の消費行動は 習慣的なものであるために，外的条件の急激な変化 の影響を受けにくいものと考えられる。1 1973 年以降 の電灯消費量は依然としてかなり増加しているが, 増加率は, 主要な電気製品がすでにかなり普及して
しまったため, 1973 年以前のように大きくはない。

\section{2. 電灯消費量の規定要因}

P。George らは，様々な消費類型の差異を説明 するものとして, 社会階層や職業構成等によって影 響を受ける所得と，都市と農村との生活様式の差を あげだ。これは電灯消費量においても同様であると みなされ, 過去の研究においても需要分析の因子に 用いられてきた ${ }^{10)}$

所得が，家庭電気製品購入を促す直接的要因であ ることは明らかであり，そのため年次的な個人所得 と電灯消費量の変化はほぼ対応してきた。都道府県 別 1 世帯あたりの個人所得と電灯消費量の関係をみ ると, $1960 ， 1965 ， 1970 ， 1975$ 年において相 関係数はそれぞれ，0.87，0.80，0.77，0.69 と年 次が進むにつれて減少してきているが，所得は説明 要因として相変わらず重要な意義を持っていると考 えられる。

都市と農村の差, および就業構造の差は, 第 1 次 産業就業者割合, あるいは第 $2 \cdot 3$ 次産業就業者割 合によってある程度示すことができる。1960 年代前 半の東京電力管内の農家と非農家の電灯負荷曲線 ${ }^{11)}$ によると, 午前と午後の負荷率のピークは, 非農家 ではそれぞれ 8 時, 21 時台にあるのに対して, 農家 では $6 ・ 7$ 時台, 17 時台に見られる ${ }^{12)}$ 。 また， 6 時 台を除いて負荷率は非農家の方が高い。これは, 起 床も就寝も早く，一般的に電灯消費量が小さい農家 の生活様式を象徽的に現わしている。しかし，1960， $1965 ， 1970 ， 1975$ 年の都道府県別第 2 。3 次産 業就業者割合と，1世帯あたりの電灯消費量との相 関係数は，それぞれ $0.89 ， 0.78 ， 0.61 ， 0.44$ とな っており，両者の関係が弱くなってきている。これ は都市と農村の生活様式の差が小さくなってきてい ることを示しているものと考えられる。

電気製品保有率の地域差は, 電灯消費量の地域差 を直接左右する。電気製品保有率の地域差は, 1960

第 2 表 所得、第 2 ・ 3 次産業就業者割合と各家庭電気機器の保有率との相関係数

\begin{tabular}{|c|c|c|c|c|c|c|}
\hline 電気機器 & 白黒テレビ & カラーテレビ & & & \multicolumn{2}{|c|}{ ルームクーラー } \\
\hline 年次 & 1960年 & 1970年 & 1960年 & 1965年 & 1970年 & 1975年 \\
\hline 所 & 0.77 & 0.77 & 0.58 & 0.52 & 0.43 & 0.21 \\
\hline 第 $2 \cdot 3$ 次産業就業者割合 & 0.88 & 0.74 & 0.87 & 0.86 & 0.76 & 0.74 \\
\hline
\end{tabular}


年代前半の白黒テレビ, 1960 年代の 洗たく機や冷 蔵庫，1970 年代前半のカラーテレビ， 1970 年代の ルームクーラーの場合におけるように，普及途上の 時期に著しい。とくにテレビ, 冷蔵庫の消費電力量 は，1975 年において従量電灯消費量のそれぞれ 19.9 $\% ， 25.2 \%$ 占め ${ }^{13)}$, 地域差を生み出す重要な要素 になっている。この保有率の地域差を生み出す要因 は電気製品によって異なる。テレビは個人所得, 第 2 - 3 次産業就業者割合のいずれとも比較的高い相 関係数を持つのに対して, 冷蔵庫, ルームクーラー は, 第 2 ・ 3 次産業就業者割合との相関係数のみが 高い(第 2 表 )。この理由は, 冷蔵庫, ルームクー ラーが都市と農村の生活様式の差に依存する度合が 強いためと考えられる。

冷蔵庫, ルームクーラー保有率は, 夏の気温等の 自然条件に影響され, 北海道, 東北よりも, 四国, 中国，九州で早くから普及してきた。そのため，東 北日本と西南日本では従量電灯月別消費パターンは 異なる。1977 年において, 中部電力, 北陸電力管 轄地域以北では，1・2月に電力消費量が最大にな るのに対して, 関西電力管轄地域以西では, $7 \circ 8$ 月の電力消費量が最も大きい ${ }^{14 ）}$ 。ームクーラーは 電力消費量が大きいため, 普及時期の早い西南日本 の冷房用電力消費量を増加させてきた。

以上のことから, 電灯消費量の分布に関する地域 性を考察するために, 個人所得と第 2 。3 次産業就 業者割合を主要な要因として取り扱うことは適当で あると考えられる。また，自然条件が冷房用電力消 費量に与える影響をも考慮に入れる必要があろう。

\section{III。電灯消費パターンの地域的差異}

\section{1. 電灯消費量の分布とその变化}

$1960 ， 1965 ， 1970 ， 1975$ 年各々の全国平均 1 世帯あたりの電灯消費量を 100 とした，都道府県 別 1 世帯あたりの電灯消費指数と，1960-1965， $1965-1970 ， 1970-1975$ 年における都道府県 別電灯消費増加率の分布を見てみよう（第 3 図およ び第 4 図 )。

第 3 図の 1960 年の分布には, 電灯消費量の地域 差が比較的明瞭に現われており。最大消費県の大阪 と，最小消費県の鹿児島の指数の差は 104.8 である。 電灯消費量は, 大阪・東京・愛知で高く, その周辺 の京都・兵庫・神奈川がこれに次いでいる。高指数
地域の広がりは小さく, 大都市圏の間に位置する滋 賀の指数は高くない。また, 東京に隣接する千葉, 埼玉の指数も低く, 東京の 3 分の 2 以下である。 巨視的に見て日本の中央部が高く，縁辺部が低い。 各地方でも九州における福岡, 中国における山陽, 四国における香川など, 地方の中心的な県の消費量 が周囲の県に比べて大きい傾向がみられる。

1965 年には，1960年と比較して地域差が減少 し，最大消費県と最小消費県の指数差が 78.7. にな った。東京, 大阪, 愛知の指数が減少し, 静岡, 奈 良や北陸 3 県の指数が増加した。1960-1965年の 5 年間で 1 世帯あたりの電灯消費量は $77 \%$ 増加し た。このことは，白黒テレビ保有率が $41.5 \%$ から $95.0 \%$ に, 洗たく機保有率が $31.6 \%$ から $72.3 \%$ に, 冷蔵庫保有率が $9.4 \%$ から $57.2 \%$ に増加することと 対応して, 家庭内の電化が進んだことを反映してい る。電灯消費量の増加率は, 概して 1960 年に消費 量の小さかった地域で大きく，大きかった地域で小 さい。とくに北関東・滋賀・福井・三重など大都市 に隣接する地域での高い増加率が特徵的であり,こ のことは都市的消費意識が周囲に広まったことを示 していると考えられる。

1970 年には電灯消費量の地域差の減少がさらに 進み, 最大消費県と最小消費県の指数差は63.4にな った。東京, 大阪, 愛知の指数がそれぞれ 107.5, 114.7，107.5に減少したのとは対照的に, 福井, 石川, 富山では $122.8,117.4,114.5$ に増加した ${ }^{15)}$ 岐阜, 長野, 山梨の指数も増加し, 高指数地域が日 本の中央地帯に広がった。九州, 四国, 北海道では すべて指数が増加したが，それぞれの地域内での相 対的分布に大きな変化はない。1965-1970年の 1 世帯あたりの電灯消費量の増加率は $54.9 \%$ であり, 以前の 5 年間に比べて小さくなった。南九州, 東北 など，以前電灯消費量が小さかった地域の増加率が 高いほか, 長野, 山陰, 岡山などの増加率が高く, 電灯消費量の大きな地域が拡大した形がみられる。

1975 年には電灯消費量の地域差の減少がさらに 進んだが，消費指数は本州中央部で大きく，遠隔地 に行くほど小さくなり，圈構造を反映した分布パタ ーンが現われている。1970-1975 年の電灯消費量 増加率は $41.4 \%$ で以前の 5 年間よりもさらに減少し た。地域的には東京と兵庫を結ぶ東海道メガロポリ ス地帯の増加率が低くなっており, 消費量の小さい 北海道や南九州で比較的高くなっている。 

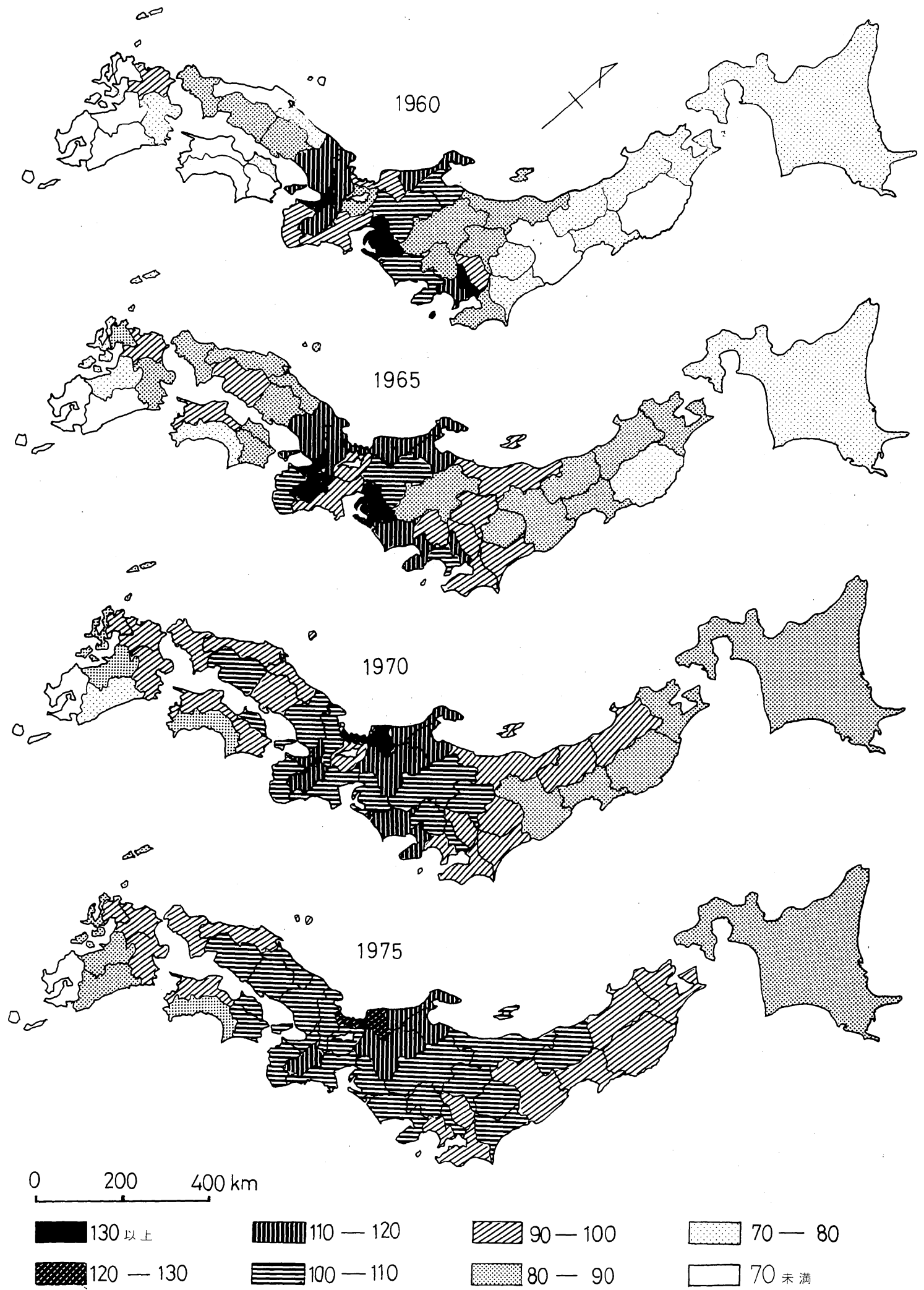

第 3 図 $1960,1965,1970,1975$ 年における都道府県別～世帯あたりの電灯消費指数（全国平均＝100） 資料「電気事業便覧」1961，1966，1971，1976 年版 


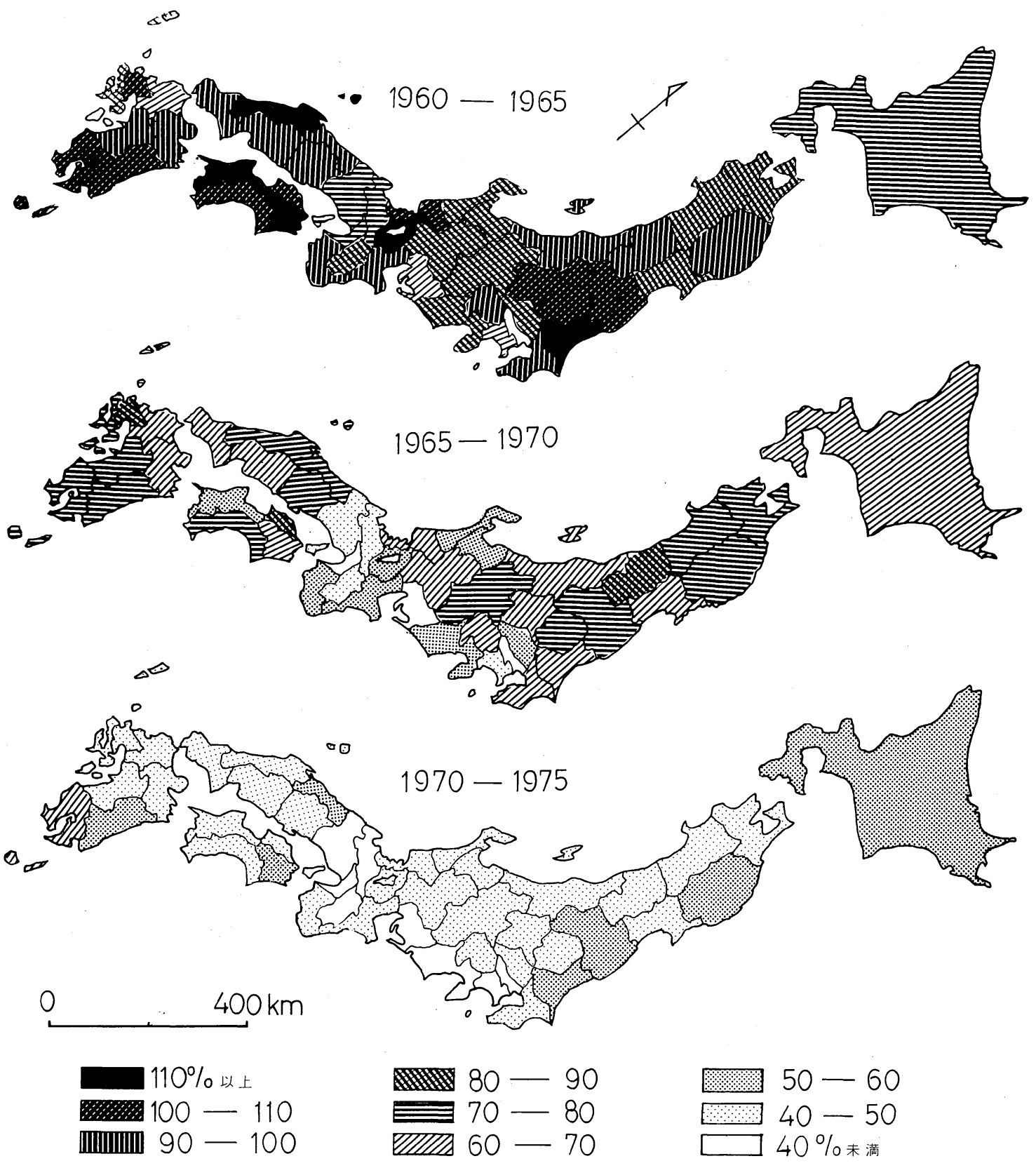

第 4 図 1960-1965, 1965-1970, 1970-1975 年における都道府県別電灯消費増加率

資料「電気事業便覧」 
このように, 電灯消費量の地域差は, 年ごとに減 少してきている。また, 消費量の大きな県の隣接地 域の増加率が高いことも特徵的であり，1960 年代に おいて電灯消費量を規定する要因として大都市から の距離が重要な意味を持っていたと考えられる。そ の理由として，家庭電力消費行動をひきおこす意識 は空間的に広がっていく性質を持つからではないか と推測できる。このことは，隣接しあう地域におけ る電灯消費量の差異が。所得などの条件の差異と比 較して小さいことをも説明している。

\section{2. 電灯消費量の分布パターンの抽出}

電灯消費量の分布に現われた所得や第 $2 。 3$ 次産 業就業者割合以外の地域的条件を考察するために, それぞれの要因が規定すると予想される各県の電灯 消費量と実際の消費量の残差をパターン化して把握 してみよう。

まず，1960，1965，1970，1975 年の各年次 において, 都道府県別 1 世帯あたりの個人所得の平 均值，あるいは第 $2 \cdot 3$ 次産業就業者割合を独立変 数とし, 電灯消費量を従属变数とする 2 種の単回帰 分析を行った。

個人所得と電灯消費量の各年次の相関については, すでに第 2 章において触れておいたが，個人所得に よって電灯消費量が説明される割合は，1960 年よ り順次～ $0.76 ， 0.64 ， 0.59 ， 0.48$ となる。同様に 第 2 。3 次産業就業者割合が電灯消費量を説明する 割合は, 1960 年より順次, $0.79,0.61,0.37,0.19$ と減少する。両独立変数の説明量は, 1960年上 1965 年においては，比較的高い值を示すが，1970 年と 1975 年になるとこの值は減少し,とくに第 $2 \cdot 3$ 次 産業就業者割合の低落が著しい。このことは, 1960 年代においては, 所得変数と就業変数は, 電灯消費 量を説明する重要な要因であったが，1970 年代に 至ってはこの重要性は低下したと言わざるをえない。

そこで次に, 回帰傾向によっては説明されない残 第 2,3 次産業就業者割合の残差

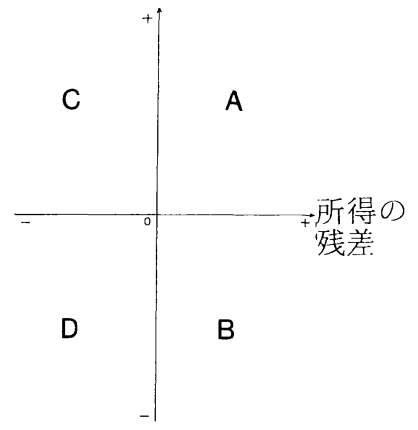

差の分布を，1960 年代の場合を含めてとくに 1970 年代を中心に検討する。このことは第 1 章でのべた ように, 各地域の伝統的な生活意識を解明する一助 となる。そのため, 単回帰分析の結果得られた残差 の值の符号とこれらの組み合わせにもとづき, 都道 府県を次の 4 類型に分類した (第 5 図)。

$\mathrm{A}$ 類型：電灯消費量が個人所得に対しても第 2 ・ 3 次産業就業者割合に対しても正の残差を持つ 地域

$\mathrm{B}$ 類型：個人所得に対して正，第 2 。 3 次産業就 業者割合に対して負の残差を持つ地域

$C$ 類型：個人所得に対して負, 第 $2 \cdot 3$ 次産業就 業者割合に対して正の残差を持つ地域

$\mathrm{D}$ 類型：個人所得に対しても，第 2 - 3 次産業就 業者割合に対してむ負の残差を持つ地域 その結果として，都道府県別に，各類型ごとに 4 時 点を通じての出現回数を地図上に示した (第 6 図 )。

分類基準からも明らかなように, $\mathrm{A}$ 類型と $\mathrm{D}$ 類型 は補完的な分布を示す。概してA類型は近畿, 北陸 3 県を中心とする日本の中央部に，D類型は，東京 周辺, 愛知等の例外を除けば, 北海道, 東北の太平 洋側, 四国, 九州などの日本の縁辺部に連続した広 がりを持つ。A類型の地域は，所得, 就業構造が規 定する以上に電灯消費量が大きく，電灯消費意識 ${ }^{16)}$ が強いと考えられる地域であり，D類型は消費意識 が弱い地域であると言えよう。

B 類型と C 類型もほぼ補完的な分布を示す。概し て B類型は山陽地方を中心とする西南日本に, C類 型は秋田, 山形, 新潟を中心とする東北日本に分布 する。B類型は第 $2 \cdot 3$ 次産業就業者割合の高さが 電灯消費量を増加させている地域であると考えられ る。この地域では C 類型の地域よりも冷蔵庫やルー ムクーラーの普及時期が早かった。これは冷蔵庫や ルームクーラーは, 所得よりも第 $2 \cdot 3$ 次産業就業 者割合によって所有が規定される度合が強い傾向を 持つためであると考えられる。また C 類型の地域よ りも一般的に夏の気温が高いことも，その高い保有 率に関倸しているであろう。C類型の分布地域は, 所得の相対的高さが電灯消費量を大きくしている地 域であると考えられる。概してこの地域ではテレビ の普及が早く。冷蔵庫やルームクーラーの普及が遅 い。

このように $4 つ の$ 年次を通して, 各県の類型の変 化が少ないのは，所得や第 $2 \cdot 3$ 次産業就業者割合 


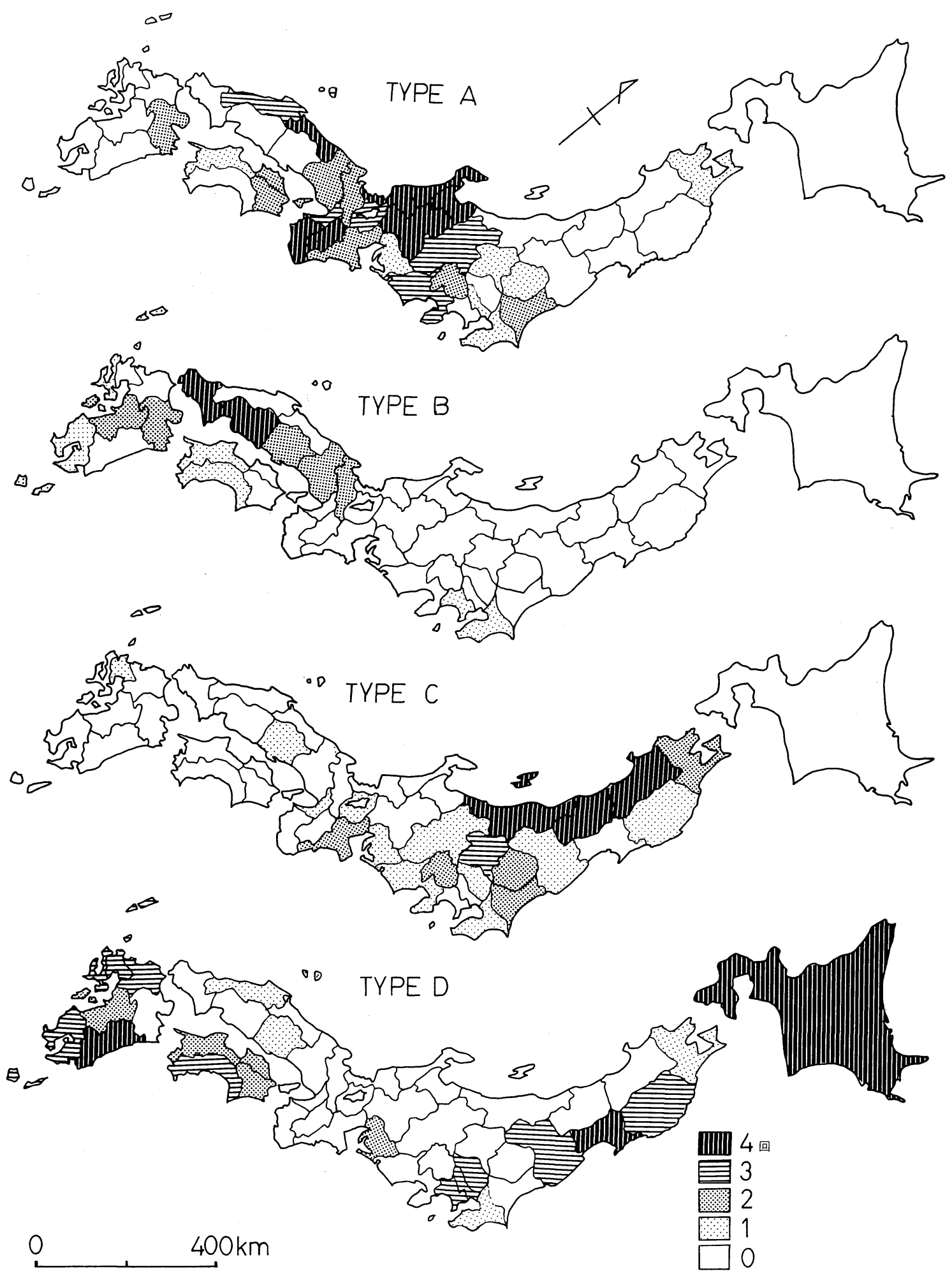

第 6 図 $1960,1965,1970,1975$ 年の 4 年次を通じての各類型の出現回数 
の増加によって電灯消費量は増加するが，基本的な 地域の人々の生活意識には大きな変化がないこと を示していると考えられる。

\section{3. 電灯消費量の残差分布パターンの地域的} 差異

前節から，A類型と D 類型は消費意識の高低を示 す指標となり， B 類型と C類型は消費構造の差異を 示す指標になると考えられる。また，4つの年次を 通して類型が変化しない地域は生活意識があまり変 化しない地域であり，変化が著しい地域は，周囲の 条件の変化によって，生活意識が複雑に変化してき
た地域であると考えられる。この指標は。各都道府 県の地域性解明に役立つものと思われる。

このために，都道府県を资のように分類した。 4 つの年次にわたってA類型の地域をA地域，2。3 年次にわたってA類型の地域を $\mathrm{A}^{\prime}$ 地域とする。4つ の年次ともに類型の異なる地域を $\mathrm{E}$ 地域, $\mathrm{A}^{\prime}$. 地域で ありかつ $\mathrm{B}^{\prime}$ 地域である地域を $\mathrm{AB}$ 地域とし，他もこ れに従う。その結果。日本は $\mathrm{A}, \mathrm{A}^{\prime}, \mathrm{AB}, \mathrm{AC}, \mathrm{AD}$, $\mathrm{B}, \mathrm{B}^{\prime} \mathrm{BD}, \mathrm{C}, \mathrm{C}, \mathrm{CD}, \mathrm{D}, \mathrm{D}^{\prime}, \mathrm{E}$ の 14 地域に分類 された(第 7 図)。

A地域は, 富山, 石川, 福井, 岐阜, 奈良, 和歌 山，鳥取である。北陸 3 県および岐阜は，電灯消費

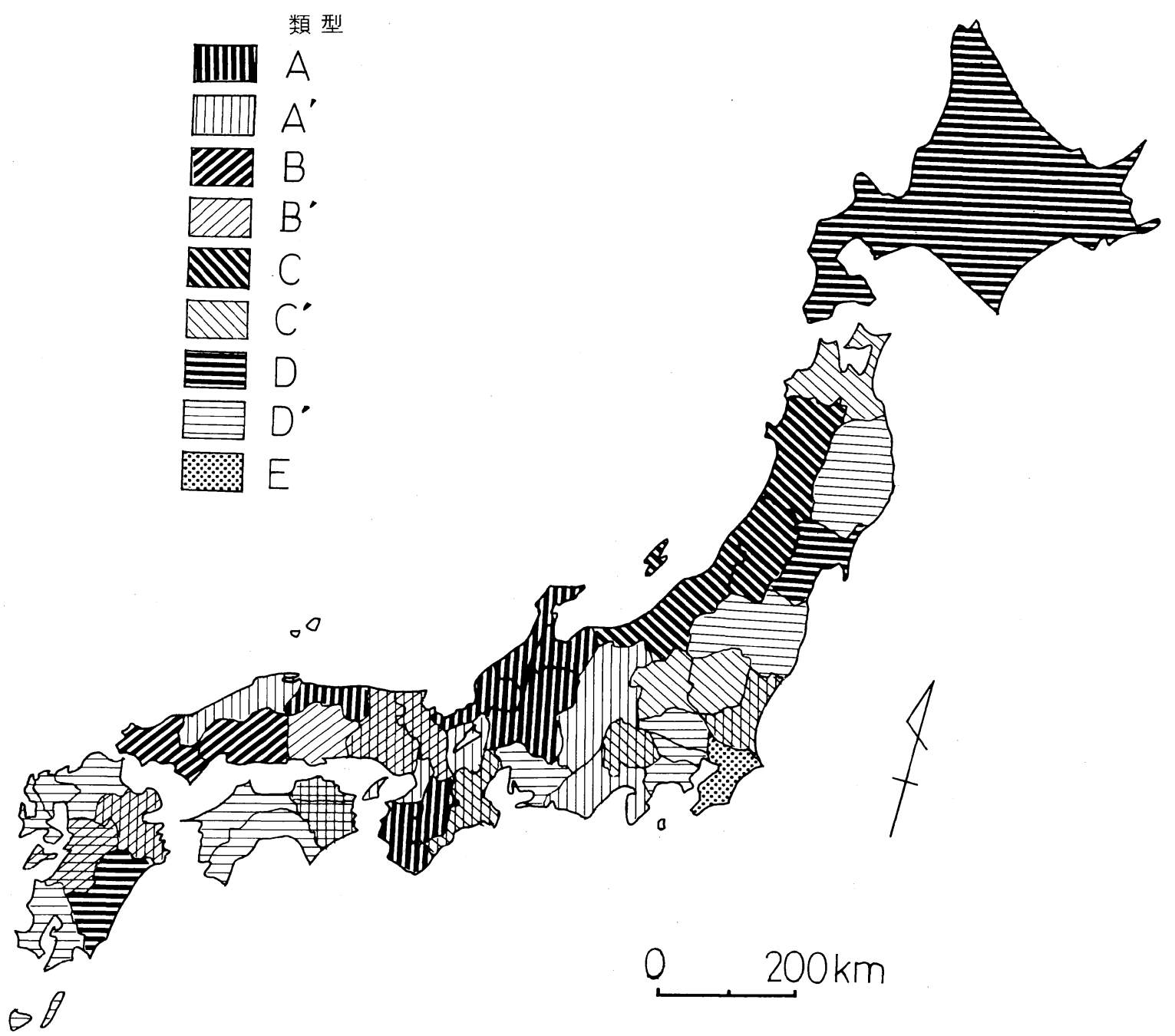

第 7 図 1 世帯あたりの電灯消費量と個人所得, 就業構造による都道府県別地域分類

注：図中の記号は本文の記号に一致する。 
量が全国で最も大きい地域であるにもかかわらず, 電灯消費量の増加率は高く, 所得等に規定される以 上に高い消費意識を保っている地域である。この大 きな消費量は，世帯あたりの居住面積が全国で最も 大きいことに影響されたものと考えられるが，独自 にその地域は，生活水準を向上させようという意識 が強い地域であるとも予想される。奈良と和歌山に は，比較的電灯消費意識が高い近畿地方の中で，大 阪・京都といった大都市に隣接しているという位置 的条件の影響が及んでいるものと考えられる。鳥取 は，中国地方の他の県と電灯消費量の大きな差はな いが。所得や第 2 ・3 次産業就業者割合が小さい県 である。 $\mathrm{A}^{\prime}$ 地域は, 長野, 静岡, 滋賀, 大阪, 島 根である。大阪は，所得や第 $2 \cdot 3$ 次産業就業者割 合が高いにもかかわらず， $1960 ， 1970 ， 1975$ 年に A 類型を示す, 非常に消費意識が高い地域である。 その他の県は都市的地域やA地域の隣接県である。

$\mathrm{AB}$ 地域は, 京都, 兵庫, および大分である。京 都と兵庫は，大阪と同様に消費意識が高い地域であ る。ルームクーラー普及率も高く, 熱帯夜日数が九 州に匹敵する近畿地方の気候条件を反映している。 大分は九州の中で独自の生活意識を持つ地域である と考えられる。AC地域は茨城, 山梨, 三重である。 山梨・三重は $\mathrm{A}$ 地域，および $\mathrm{A}^{\prime}$ 地域に，茨城は首都 地域に隣接した地域である。 $\mathrm{AD}$ 地域は香川, 徳島 であり, 比較的所得や第 $2 \cdot 3$ 次産業就業者割合と 対応した消費量を示す地域である。

$\mathrm{B}$ 地域は広島, 山口, $\mathrm{B}^{\prime}$ 地域は岡山である。この 地域は, 第 $2 \cdot 3$ 次産業就業者割合の高さや夏の気 温の高さが電灯消費量を大きくしているB類型の特 徵が強い地域である。熊本は一般的に消費意識の低 い九州の中で B 類型の性質を持つ BD地域となって いる。

C地域は秋田・山形。新潟である。この地域は比 較的農村的な性格が強い地域でありながら，それが 所得の低さや消費意識の弱さには現われない地域で ある。C’地域は, C地域に近接する青森, 杤木, 群 馬である。

D地域には北海道, 宮城, 宮崎が含まれる。北海 道・宮崎は, 日本の中央部からの遠隔性が影響して いる地域であろう。宮城は東北の他の地域に比べて, 所得や第 2 ・3 次産業就業者割合が高いのに対して, 消費量の差が小さい。 $\mathrm{D}^{\prime}$ 地域は, 岩手, 福島, 埼玉, 東京, 神奈川, 愛知, 愛媛, 高知, 福岡, 佐賀,
長崎, 鹿児島である。埼玉, 東京, 神奈川, 愛知は 所得や第 $2 \cdot 3$ 次産業就業者割合が相対的に高いた めに $\mathrm{D}^{\prime}$ 地域となったが, 消費意識は, 大阪, 京都な どよりも低いことは明らかであろう。その他のD $\mathrm{D}^{\prime}$ 地 域は, 中央部からの遠隔性が影響した地域であると 考えられる。

E地域は千葉である。千葉は 1960 年 から順次 $\mathrm{A}$, $\mathrm{C}, \mathrm{D}, \mathrm{B}$ と変化した。元来東北日本的な $\mathrm{C}$ 類型の 性格を持っていたが，大都市への近接性や新住民の 流入等によって類型がしばしば変わる地域であると 考えられる。

\section{N。むすび}

本稿の目的は, 都道府県別 1 世帯あたりの電灯消 費量分布の時間的, 空間的特徵を把握し, 電灯消費 量の分布とその変化に現われた日本の各地域の地域 性を考察することであった。本研究で検討した内容 を要約すると次のようになる。

1. 家庭電力消費量を意味する電灯消費量は, 商工 業用電力消費量を意味する電力消費量に比べて, 年 次ごとの増加率は高く, 経済変動の影響を受けにく い。

2. 1970 年代半ばまでには主要な電気製品の 保有 率が飽和状態に達したために, 1970 年代半ば以降 の電灯消費量増加率は，1960年代ほど大きくはな い。

3. 電灯消費量分布は, 1960 年には東京・大阪 愛知の消費量がとくに大きく，地域差が著しい形態 を示していたが，年次が進むにつれて地域差が減少 し，1970 年代には一般的に本州中央部の消費量が 大きく, 遠隔地に行くほど小さくなる圈構造が反映 した形態を呈するようになった。

4. 単回帰分析によると, 所得と第 $2 \cdot 3$ 次産業就 業者割合は，1960年代においては,電灯消費量を説 明する重要な要因であったが，1970 年代に至って は,この重要性は低下した。

5. 残差の分析によれば。東北日本と西南日本の電 灯消費パターンは異なる。一般的に前者は, 所得の 高さが電灯消費量を大きくし，テレビが比較的早く 普及した地域として, 後者は, 第 $2 \cdot 3$ 次産業就業 者割合の高さと夏の気温の高さが電灯消費量を大き くしている, 冷蔵庫やルームクーラーの普及が早い 地域として特徵づけられる。 
6. 残差の值の符号とその組みあわせによって日本 を 14 の地域に分類した。この分類は，各地域間に電 灯消費構造の違いが存在することを示している。ま た。この分布には, 従来あまり考察されてこなかっ た地域の人々の生活意識の差異が反映しているもの と考えられる。

\section{注}

1）佐久間孝・荒井泰男：「府県別にみた従量電灯 の消費構造」, 『電研レポート』，1965， $\mathrm{p} \mathrm{p}$ 。 $1545 \sim 1572$ 。

2）電力中央研究所：『民生用電力需要構造と動向 等に関する調査, 委託調査結果報告書』1980, $\mathrm{pp}$ 。 $51 \sim 84$ 。

3）洗たく機, 冷蔵庫, 掃除機, 白黒テレビ・カラ ーテレビ, こたつ,ルームクーラーの普及率とそ の容量, および 1975 年における各機器の 年間使 用時間を用い，1975 年を基準として 指数化した もの。

4）小笠原は，下田市内の都市度を光度によって表 現したが，この光度は各家庭の消費意識を表現し たものとは言い難い。小笠原義勝：「地方都市の 都市度の研究」, 地理学評論 $13-, 1937, \mathrm{pp}$ 。 $478-493$ 。

5） 1976 年の東京電力電気供給規定によると,従量 電灯甲は「電灯または小型機器を使用する需要で, 使用する最大電流が 5 A以下のもの」, 従量電灯 乙は，「契約電流が $10 \mathrm{~A}$ 以上かっ $60 \mathrm{~A}$ 以下の もの」と定義されている。

6）通商産業省資源エネルギ一庁公益事業部編：昭 和 53 年度電力需給の概要』, 1978，p。206。

7) 斎藤観之助:「電力需要の価格分析」, 電力経 済研究 8，1974，pp. 71-82.

8）[前掲 7) p. 81。]によると, 電灯の価格弾性 值はー0.415 ー 0.437で, 鉄鋼業用電力の-0.785 $\sim-0.856$, 化学工業用電力の-1.18 - 1.20 ,機 械工業用電力のー0.59 の絶対値よりも小さく, 霓 灯消費量は比較的価格の変動の影響を受けにくい。
9) George, $P$ 。 et al "La géograqhie active"

P。U。 $F_{2}$ Paris, 1964, ( 日本語訳, 未尾他訳『行 動の科学としての地理学』, 大明堂, 1969, pp。 202-206。

10）個人所得，あるいは都市と農村の生活様式の差 異に着目して電灯需要を分析した研究には次のよ うなものがある。前掲 1） pp。1545～1572。前 揭 2) pp。51 84。服部常晃：「電灯需要の分析」, 電力経済研究 10,1976, pp. 63 85. 服部常晃 : 「家庭用エネルギー需要の所得階層別分析」, 電力経済研究 $11,1977, p p 。 35 \sim 50$.

11）負荷率とは電気器具のストックとその稼動率の 積であり,この積の值の 1 日の時間ごとの変化を 示した曲線が負荷曲線である。

12）前掲 1) P. 1554。

13）前掲 6) $\mathrm{p}_{\mathrm{o}} 379$.

14) 前掲 6) $\mathrm{pp}$ 。211 216。

15） 1 世帯あたりの人数には東京の 2.7 人，福井の 4.1 人というように大きな差があるために単純な 比較はできない。1 人あたりの電灯消費量では東 京が最高であり, 以下大阪・京都・兵庫。神奈川 の順に続く。

16)ここでいう「電灯消費意識」とは, 家庭電気 製品を購入したり，使用したりする人々の性向 を意味する。

付 記

本稿は, 昭和 54 年 12 月に筑波大学へ提出した卒 業論文を加筆, 修正したものである。本稿の作成に あたり, 立正大学の高野史男教授, 筑波大学の山本 正三教授をはじめ, 高橋伸夫, 石井英也, 市南文一 諸先生方の指導を受けました。また，電力中央研究 所の加藤芳夫先生には，絶えず励ましの言葉をいた だきました。記して謝意を表します。

(なかがわ ただし＝筑波大学大学院生 $)$ 


\title{
DISTRIBUTION OF ELECTRICITY CONSUMPTION PER HOUSEHOLD
}

\author{
IN JAPAN
}

\section{Tadashi NAKAGAWA*}

The purpose of this study is to present the distribution of electricity consumption per household in Japan and its change during the period from 1960 to 1975.

This study deals with the consumption of electricity for home use, which has increased more rapidly compared to that for commercial-industrial use(Fig. 1), and was less influenced by economic change in the period after 1960.

The first step of this study is to discuss the factors of the distribution of electricity consumption. Income and the ratio of non-agricultural workers of each prefecture which was used to measure the degree of urbanization were discussed. These values have the high coefficient of determination of 0.76 and 0.79 respectively with electricity consumption in 1960 . These coefficients, however, are much smaller in 1970's. The purchase of air conditioner is influenced in part by climatic condition.

The distribution of electricity consumption per household and its rate of increase in each five years are shown in Fig. 3 and Fig. 4. In 1960, electricity consumption was large in urbanized prefectures of Osaka, Tokyo, and Aichi, and small in rural area. However, this difference became smaller in 1965 and 1970. In 1975, the consumption was large in central Japan with its core in Hokuriku District and small in Hokkaido and Kyushu.

Two sets of regression analysis are made in each year with income per household or ratio of non-agricultural workers of each prefecture as an independent variable, and electricity consumption per household as a dependent variable. If we raise the level of generalization of residual distribution, we can identify two patterns as follows. Central Japan has high level of electricity consumption, whereas rest of Japan has low level of consumption. Electricity consumption in North-East Japan is more influenced by income, whereas the factor of urbanization is stronger in South-West Japan.

Regional devision of Japan in terms of electricity consumption is the subject for a future study, although Fig. 7 is one of the examples.

${ }^{*}$ Graduate Student, University of Tsukuba 